\title{
Correction: Racial and ethnic disparities in outcomes through 1 year of life in infants born prematurely: a population based study in California
}

Kayla L. Karvonen (D) Rebecca J. Baer • Elizabeth E. Rogers • Martina A. Steurer (D) Kelli K. Ryckman (D) Sky K. Feuer · James G. Anderson (D) - Linda S. Franck (D) Dawn Gano (D) Mark A. Petersen (D) - Scott P. Oltman • Brittany D. Chambers · John Neuhaus · Larry Rand - Laura L. Jelliffe-Pawlowski • Matthew S. Pantell (D)

Published online: 29 March 2021

(c) The Author(s), under exclusive licence to Springer Nature America, Inc. 2021

Correction to: Journal of Perinatology

https://doi.org/10.1038/s41372-021-00919-9
One of the authors of this article has been misspelled. Mark A. Peterson should be Mark A. Petersen.

The original article has been corrected. 